\title{
Program Educational Objectives Definition and Assessment for Quality and Accreditation
}

\author{
http://dx.doi.org/10.3991/ijep.v3i3.2777 \\ Noureddine Abbadeni, Ahmed Ghoneim, and Abdullah Alghamdi \\ King Saud University, Riyadh, Kingdom of Saudi Arabia
}

\begin{abstract}
Academic accreditation of degree programs is becoming an important mean for many institutions to improve the quality of their degree programs. Many programs, in particular computing and engineering, offered by many schools have engaged in the accreditation process with different accreditation bodies. Accreditation bodies include ABET in USA, ABEEK in South Korea, JABEE in Japan, etc. Probably the most known accreditation body in the Unites States of America for engineering, computing, technology, and applied science programs is ABET. A key problem towards the satisfaction of accreditation criteria for most of accreditation agencies including ABET is the appropriate definition and assessment of program educational objectives for a specific degree program. Program Educational Objectives are important as they represent the ultimate mean to judge the quality of a program. They related directly to student outcomes and curriculum of a degree program. We propose a set of guidelines to help understand how program educational objectives can be defined and assessed. We relate and use examples from our practical experience acquired while working on the ABET accreditation of a Software Engineering program.
\end{abstract}

Index Terms-Accreditation; Program Educational Objectives; Assessment; Curriculum; Software Engineering Programs

\section{INTRODUCTION}

Accreditation of academic programs is a peer-reviewed and voluntary process used by academia to assess and evaluate the quality of their degree programs. In United States, and in some other countries, ABET (previously Accreditation Board for Engineering and Technology) is becoming the leader in accrediting Engineering, Computing, Technology, and Applied Science programs [1, 5]. ABET is structured in four main commissions; each covers a list of relevant programs and defines for them a list of relevant accreditation criteria. ABET commissions are: Engineering, Computing, Technology, and Applied Sciences. Accreditation criteria are respectively Engineering Accreditation Criteria (EAC) for engineering programs, Computing Accreditation Criteria (CAC) for computing programs, technology accreditation criteria (TAC) for technology programs, and Applied Sciences Accreditation Criteria (ASAC) for applied sciences programs [1, 2, 5]. ABET accreditation criteria are divided in two categories $[2,5]$ :

- General criteria, applicable to all programs in a category (e.g. Engineering programs), include students, program educational objectives (PEO), student outcomes (SO), assessment and continuous improvement, curriculum, faculty, facilities, and institutional support.
- Program criteria, applicable to a specific program (e.g. Software Engineering), depend on each program. For example, a Software Engineering program must demonstrate that graduates have "the ability to analyze, design, implement, verify, maintain, and apply software systems".

In addition to general and program criteria, ABET accreditation is based on a list of policies and procedures described in the ABET APPM (Accreditation Policies and Procedures Manual) that must be satisfied in order to fulfill accreditation [3]. For example, in order to apply for ABET accreditation, a program must have graduates prior to the on-campus visit (or the academic year preceding the on-campus visit). While most of papers in the literature of educational assessment focus on student/program outcomes $[4,8]$, very little attention was given to program educational objectives. The focus of this paper is on the program educational objectives of an educational degree program. We discuss the definition and assessment of program educational objectives by considering engineering and computing programs. We show examples from a Software Engineering program to support and illustrate the ideas presented. Note that Software Engineering, although a computing discipline, is classified by ABET as an engineering discipline.

The importance of program educational objectives of a degree program comes from the fact that they represent the achievements students will attain few years after graduation. PEOs represent then the ultimate judgment of a relevance and success of a degree program. In addition program educational objectives have a direct link with student outcomes and curriculum of a degree program. Curriculum and student outcomes prepare students to achieve PEOs. Consequently if students after they graduate they do not meet the PEOs defined for the program, this indicates that there is probably issues with the curriculum and student outcomes of a degree program. Curriculum designers must consider carefully program educational objectives and make sure the curriculum and the outcomes will prepare students towards the achievements of program educational objectives $[11,12,13,14,15]$.

The paper is organized as follows:

- We propose a general framework under which the definition and assessment of PEOs can be performed.

- We explain and discuss them some guidelines that can be considered when defining a list of relevant program educational programs for a specific program. We show the list of program educational objectives defined for our Software Engineering program. 
- We discuss, then, the links between program education objectives and the institutional mission and show an example of mapping between them.

- We discuss, then, the links between program educational objectives and student outcomes as well as with curriculum and show an example of mapping between them.

- We focus then, after defined program educational objectives and mapped them with the institutional mission and the student outcomes, on the assessment of attainment of program educational objectives and discuss which assessment instruments and processes can be applied, and show some analysis and improvement actions from a software engineering program.

- We, finally, conclude the paper by summarizing the main ideas underlining the definition and assessment of program educational objectives.

\section{GLOBAL FRAMEWORK FOR THE DEFINITION AND ASSESSMENT OF PEOS}

Figure 1 shows the global framework for the definition, assessment, and revision of program educational objectives.

As explained in the introduction, PEOs are broad statements describing the achievements graduates from a specific program should attain few years after graduation. The definition and revision of the program educational objectives are initiated by the accreditation committee and discussed / approved at the department council, which includes all faculty members. Comments and input on the program educational objectives can also be sought from the members of the advisory Board. Students also give their input on educational objectives through their representatives in the advisory board as well as through a special meeting with them. Usually the advisory board meetings have a period of open discussion during which issues related to PEOs are particularly discussed. However the discussion is not limited to program educational objectives, but extends to curriculum, student outcomes, etc. Obviously any change in PEOs might have an impact on student outcomes, curriculum, etc. The accreditation committee study the impact of such changes and define a list of changes (if any) pertaining to student outcomes, curriculum, etc. Upon agreement and approval of any new actions by the advisory Board members, the accreditation committee of the program starts working to define and implement the resulting change. The process of establishing and revising program educational objectives can be summarized briefly as follows:

- The program accreditation committee established a first draft of program educational objectives (PEOs) considering the mission of the program.

- The establishment of PEOs took in consideration the institutional mission at different levels: University, College, Department and Program.

- The department council reviewed the PEOs proposed by the accreditation committee. Some changes were proposed by faculty members and the PEOs were approved by the de department council.

- PEOs must be also presented and explained to students in a meeting with them. Students can ask questions to understand the PEOs and can even propose

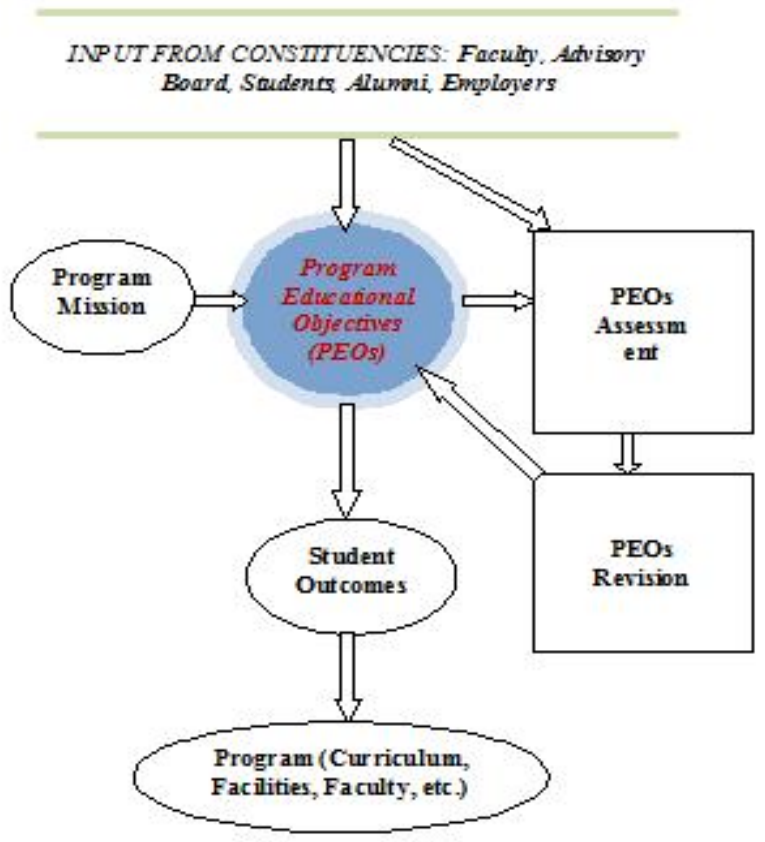

Figure 1. General Framework for the definition, assessment, and revision of the program educational objectives (PEOs)

changes to the PEOs. Students should have also the chance to provide their feedback on PEOs through their representatives in the advisory board.

- The PEOs must be discussed with the external members of the advisory board and students (through their representatives) and comments were sought from them in order to review and modify PEOs.

- Each period of 2-3 years, there should be an assessment of the attainment of the PEOs defined for the program through different instruments including the advisory board meeting, focus group survey, employers' survey, and alumni survey.

- If any change results from the assessment process, PEOs are revised and updated accordingly.

- Obviously any change to PEOs might have an impact on Student Outcomes, which, in turn, might have an impact on the curriculum itself. So if this is the case, the impact of updating PEOs on student outcomes and curriculum must be studied and any required change to student outcomes and/or curriculum must be determined.

- Then, the assessment process continues every 2-3 years to evaluate the attainment of the new PEOs. Then the process starts again.

Details about assessment are explained in section VI.

\section{Defining Program EdUCATIONAL OBJectives}

Program educational objectives are broad statements representing the expected achievements graduates from a program are supposed to attain few years after graduation (usually 3 to 5 years and more) [2, 6, 7]. In other words, program educational objectives represent the ambitions the key stakeholders of a degree program have for their students after they graduate and go to the job market and active life.

Program educational objectives shall cover both technical and professional aspects of the expected achieve- 
ments. Typical educational objectives cover the followings:

- Achievement in terms of technical skills required in the profession for which the program prepares students (software engineers, computer programmers, database architects, etc.).

- Achievements in terms of professional, ethical, and communicational aspects required by the profession for which the program prepares students (team work, ethical behavior, effective communication, etc.)

- Achievements in terms of management and leadership skills (project managers, directors, CTOs, CEOs, etc.)

- Achievements in terms of life-long learning and continuous education (certifications, conferences and workshops attendance, etc.)

- Achievements in terms of advanced and graduate studies pursuing (graduate studies, research careers, etc.)

- Other aspects could be considered when defining educational objectives such as the ability to engage in entrepreneurship activities (for engineering programs in particular).

Defining the program educational objectives should be done with the full involvement of all key stakeholders including faculty members, students, advisory board members, alumni, and employers of graduates. Usually the faculty members, involved in the program, propose a first draft of educational objectives, and then the other stakeholders interfere in the process and bring their additions to the first draft. Input from different stakeholder could be collected through various means including meeting (such as the advisory board meeting), surveys (such as the employer survey), etc.

A list of program educational objectives, following the guidelines mentioned above, defined for a software engineering program is given in Table I. Note that program educational objectives must be consistent short statements. They should be published and accessible to all key stakeholders including students, faculty members, members of the advisory board, parents, etc. They should be published at least on the web site of the program and program handbook/catalog. In addition, they can be posted on various new media such as facebook, twitter, etc. The idea is that all stakeholders and interested people in the program should be aware of the program education objectives of the program.

\section{Linking Program Educational ObJECtives to INSTITUTIONAL MISSION}

Program educational objectives should be in total symbiosis with the mission of the institution in which the program is offered. As depicted in Fig. 1, the institutional mission can be at different levels including the university mission, the college mission, the department mission, and the program mission. The program mission serves the department mission; the department serves the college mission; and the college mission serves the university mission. To show clearly these links between different missions, a breakdown of each mission to its key elements is necessary (Table II).

TABLE I.

EXAMPLE OF PEOS DEFINED FOR A SOFTWARE ENGINEERING PROGRAM

\begin{tabular}{|c|l|}
\hline PEO \# & \multicolumn{1}{c|}{ Description } \\
\hline PEO 1 & $\begin{array}{l}\text { Possess essential professional software engi- } \\
\text { neering skills that make them confident to } \\
\text { develop high-quality software solutions in } \\
\text { various application domains under various } \\
\text { realistic constraints. }\end{array}$ \\
\hline PEO 2 & $\begin{array}{l}\text { Engage and succeed in their professional } \\
\text { careers through team work, ethical behavior, } \\
\text { proactive involvement, and effective com- } \\
\text { munication. }\end{array}$ \\
\hline PEO 3 & $\begin{array}{l}\text { Demonstrate an understanding of the im- } \\
\text { portance of life-long learning through pro- } \\
\text { fessional development, practical training, } \\
\text { and specialized certifications. }\end{array}$ \\
\hline PEO 4 & $\begin{array}{l}\text { Assume progressively managerial, leading, } \\
\text { and influential roles in their organizations } \\
\text { and communities. }\end{array}$ \\
\hline PEO 5 & $\begin{array}{l}\text { Pursue postgraduate studies and succeed in } \\
\text { academic and research careers. }\end{array}$ \\
\hline
\end{tabular}

An example of missions at different levels along with their mapping to program education objectives defined for a software engineering program are given below.

University mission: To provide students with a quality education, conduct valuable research, serve the national and international societies and contribute to Saudi Arabia's knowledge society through learning, creativity, the use of current and developing technologies and effective international partnership.

College mission: To advance the frontiers of knowledge and to prepare creative minds in computing disciplines with commitment to serve the community in order to participate in moving towards a knowledge-based economy through developing an environment that stimulates excellence, creativity, and innovation in education and research.

Department mission: To make a significant contribution to the national goal of promoting the knowledge society through high-quality education, innovative research, and services to the community in the field of software engineering.

Program mission: To produce highly qualified software engineers that serve the society needs and contribute to transform the society into a Knowledge Society.

The university, college, department, and program missions along with program educational objectives must be public and known to all stakeholders including students, faculty members, advisory board, employers, etc. They 
PAPER

Program Educational ObJectives Definition And AsSessment for Quality and ACCREDitation

\begin{tabular}{|c|c|c|c|c|}
\hline \multicolumn{2}{|c|}{ Program Mission } & \multicolumn{2}{c|}{ Department Mission } \\
\hline $\begin{array}{c}\text { Produce highly } \\
\text { qualified } \\
\text { software } \\
\text { engineers }\end{array}$ & $\begin{array}{c}\text { Contribute to } \\
\text { transform the society } \\
\text { into a knowledge } \\
\text { society }\end{array}$ & Serves & $\begin{array}{c}\text { Provide high } \\
\text { quality teaching }\end{array}$ & $\begin{array}{c}\text { Promote the } \\
\text { knowledge } \\
\text { society }\end{array}$ \\
\hline \begin{tabular}{|l|l|l|l|} 
Provide quality \\
education
\end{tabular} & $\begin{array}{c}\text { Contribute to the } \\
\text { knowledge society }\end{array}$ & Serves & $\begin{array}{c}\text { Prepare creative } \\
\text { minds }\end{array}$ & $\begin{array}{c}\text { Participate in } \\
\text { moving towards } \\
\text { a knowledge- } \\
\text { based economy }\end{array}$ \\
\hline
\end{tabular}

Figure 2. Example of Relationships between missions of the Program, the Department, the College, and the University

can be available in students' handbooks and university catalogs as well as on the web sites of the university, college and department. The different missions are linked and aligned with each other as follows:

- The mission of the program contributes towards achieving the mission of the department. In fact, the mission of the program focuses on producing highquality software engineers and transforming the society into a knowledge society, which are in total alignment with the mission of the department which insists in particular on high-quality teaching and contribution towards the knowledge society.

- The mission of the department contributes towards achieving the mission of the college. In fact, the mission of the department focuses on high-quality teaching and contribution towards the knowledge society, which are in total alignment with the mission of the college which insists in particular on the preparation of analytic and creative minds as well as transforming the society into an avant-garde society.

- The mission of the college contributes towards achieving the mission of the university. In fact, the mission of the college focuses on the preparation of analytic and creative minds as well as transforming the society into an avant-garde society, which is in total alignment with the mission of the university which insists in particular on providing distinctive education and building the knowledge economy.

In addition, and in order to show clearly the links between program educational objectives and institutional mission, a mapping should be provided between each program educational objective and different elements of the institutional mission at different levels (university, college, department, and program). Table II shows an example of mapping between program educational objectives and the institutional mission. It shows the contribution of each PEO towards achieving the University, college, department, and program missions. All missions defined at the university, college, department, and program levels insist on the importance of moving the society towards a society based on the knowledge economy. The PEOs of the program insist on professional skills, team work, ethical behavior, continuous learning, leadership, and graduate studies. These dimensions of the PEOs of the program are obviously consistent with the mission of the program, department, college, and university. They strongly con- tribute towards moving the society towards a knowledgebased society.

\section{Linking PRogram EdUCATIONAL ObJectives to STUDENT OUTCOMES AND CURRICULUM}

While student outcomes represent the knowledge, skills, and capabilities students should possess by the time of graduation, program educational objectives represent the achievements graduates should attain few years (3 to 5 years and more) after graduation. Student outcomes should necessarily contribute to prepare students to achieving the program educational objectives. In order to show clearly the link between student outcomes and program educational objectives, a mapping should be provided to show which outcome is contributing to the achievement of which program educational objective.

Table III provides an example of mapping between program educational objectives and student outcomes done for a software engineering program. Note that student outcomes correspond to criterion 3 of the ABET general accreditation criteria. For more details about these outcomes, refer to $[1,4,8]$.

Note that student outcomes are mapped to different courses in the curriculum of a specific program. Consequently there is a link between the program curriculum and the program educational objectives via student outcomes. In fact, specific courses in a curriculum will cover specific student outcomes and these student outcomes will participate to prepare students achieving specific educational objectives. Table $\mathrm{V}$ at the end of this paper shows a sample of mapping between student outcomes and courses in a Software Engineering curriculum. For example, from Table $\mathrm{V}$ we can see that student outcome (e) that deals with the ability of students to identify and solve software engineering problems is covered in several courses including software requirements engineering, software process and modeling, software architecture and design, software construction, software project management, and capstone project. From Table III, we can see that student outcome (e) contributes to prepare students towards the achievement of PEO 1 (Possess essential professional software engineering skills that make them confident to develop high-quality software solutions in various application domains under various realistic constraints) and PEO 5 (Pursue postgraduate studies and succeed in academic and research careers). 
TABLE II.

EXAMPLE OF MAPPING BETWEEN PROGRAM EDUCATIONAL OBJECTIVES AND INSTITUTIONAL MisSION

\begin{tabular}{|c|c|c|c|c|c|}
\hline \multirow[b]{2}{*}{ Mission Statements } & \multicolumn{5}{|c|}{ Program Educational Objectives } \\
\hline & 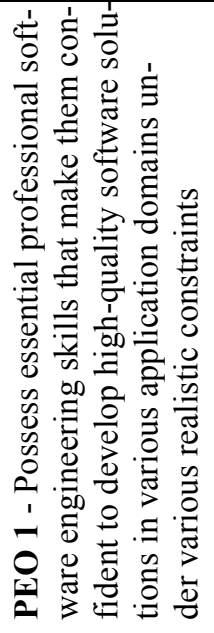 & 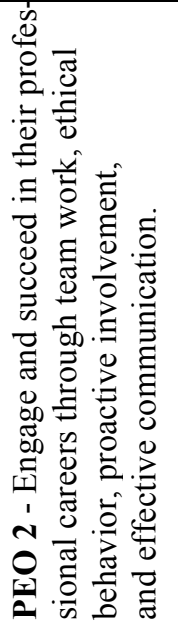 & 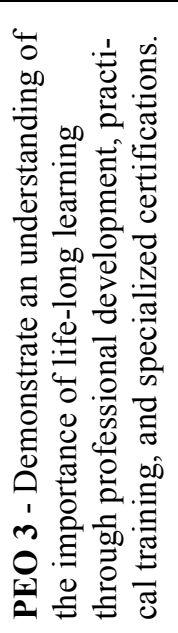 & 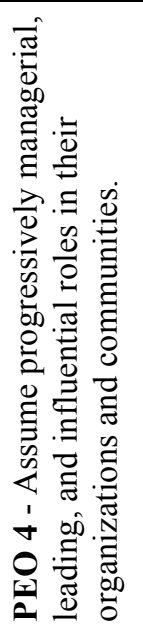 & 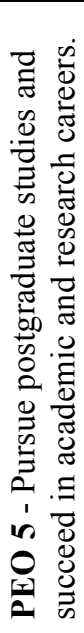 \\
\hline \multicolumn{6}{|c|}{ University Mission } \\
\hline Provide quality education & $\mathrm{H}$ & $\mathrm{H}$ & $\mathrm{H}$ & $\mathrm{H}$ & $\mathrm{H}$ \\
\hline Contribute to the knowledge society & $\mathrm{H}$ & $\mathrm{H}$ & $\mathrm{H}$ & $\mathrm{H}$ & $\mathrm{H}$ \\
\hline \multicolumn{6}{|c|}{ College Mission } \\
\hline Prepare creative minds & $\mathrm{H}$ & $\mathrm{M}$ & $\mathrm{M}$ & $\mathrm{M}$ & $\mathrm{H}$ \\
\hline $\begin{array}{l}\text { Participate in moving towards a } \\
\text { knowledge-based economy }\end{array}$ & $\mathrm{H}$ & $\mathrm{H}$ & $\mathrm{H}$ & $\mathrm{H}$ & $\mathrm{H}$ \\
\hline \multicolumn{6}{|c|}{ Department Mission } \\
\hline Provide high quality Teaching & $\mathrm{H}$ & $\mathrm{H}$ & $\mathrm{H}$ & $\mathrm{M}$ & $\mathrm{H}$ \\
\hline Promote the knowledge society & $\mathrm{H}$ & $\mathrm{H}$ & $\mathrm{H}$ & $\mathrm{H}$ & $\mathrm{H}$ \\
\hline \multicolumn{6}{|c|}{ Program Mission } \\
\hline $\begin{array}{l}\text { Produce highly qualified software } \\
\text { engineers }\end{array}$ & $\mathrm{H}$ & $\mathrm{H}$ & $\mathrm{H}$ & $\mathrm{M}$ & $\mathrm{M}$ \\
\hline $\begin{array}{l}\text { Contribute to transform the society } \\
\text { into a knowledge society }\end{array}$ & $\mathrm{H}$ & $\mathrm{H}$ & $\mathrm{H}$ & $\mathrm{H}$ & $\mathrm{H}$ \\
\hline
\end{tabular}

(H: High; M: Medium; L: Low)

\section{Assessing Program Educational ObJectives}

\section{A. Assessment Instruments and Processes}

Assessing program educational objectives is very important and aims to discover whether the defined educational objectives are being attained by graduates after they hit the employment market or not. If not, corrective and improvement actions must be taken. Fig. 2 depicts the instruments (methods) to be used in the assessment and evaluation processes related to PEOs and shows how they will be used in closing the assessment loop:

- The instruments intended to be used to collect data for the assessment of educational objectives are: advisory board meeting, focus group survey, alumni survey, employer survey, and face-to-face meetings with alumni in their employer site. Table VI summarizes these assessment instruments along with other important attributes including frequency of assessment, who collects the data, from whom the data is collected, how the data is maintained, etc.

- The data collected through the PEOs instruments are analyzed to identify clearly potential issues. A set of metrics are calculated (depending on the data) in or- der to serve as indicators as for the attainment of targets.

- An improvement plan consisting of a list of improvement actions are then decided based on the analysis findings for the non-attained targets. These improvement actions can impact any element of the program including curriculum, PEOs, SOs, facilities, faculty, etc.

- Then another assessment cycle is conducted in order to assess and evaluate whether the changes brought to the program based on the assessment and evaluation in the previous cycle have resolved the identified issues or not.

PEOs assessment must be evidence-based. That is, each assessment applied on PEOs must be documented and kept as a proof. The involvement of faculty members in the assessment process is very important and can be organized through various committees. The main committees that should be involved in the assessment and evaluation of program education objectives include at least an assessment \& continuous improvement committee as well as the department council for final approval. 


\begin{tabular}{|c|c|c|c|c|c|}
\hline \multirow[b]{2}{*}{ SWE Student Outcomes } & \multicolumn{5}{|c|}{ SWE Program Educational Objectives } \\
\hline & 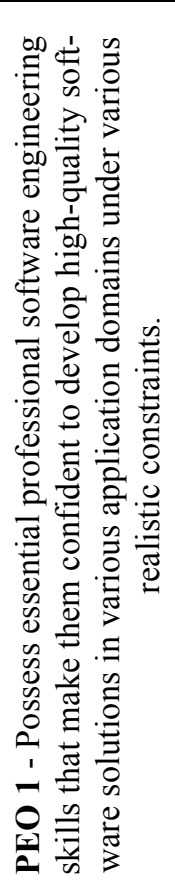 & 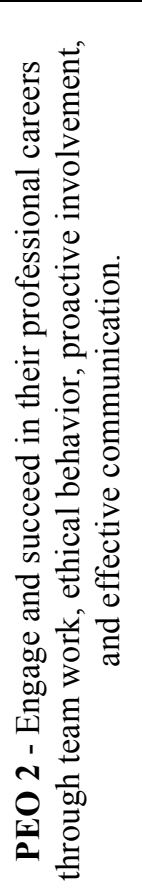 & 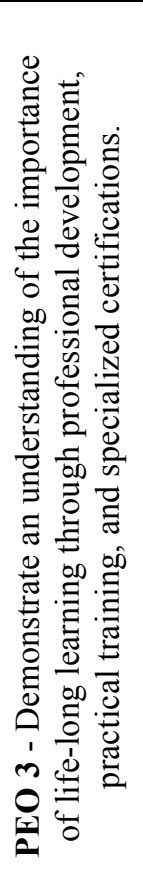 & 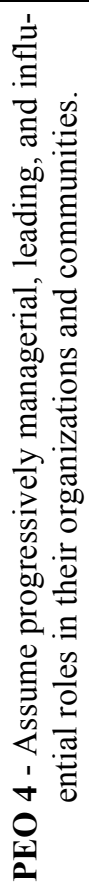 & 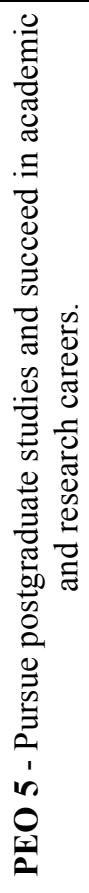 \\
\hline \multicolumn{6}{|c|}{ General Engineering Student Outcomes } \\
\hline $\begin{array}{l}\text { (a) Ability to apply knowledge of mathematics, science, and } \\
\text { engineering }\end{array}$ & $\mathbf{H}$ & & & M & $\mathbf{H}$ \\
\hline $\begin{array}{l}\text { (b) Ability to design and conduct experiments, as well as to } \\
\text { analyze and interpret data }\end{array}$ & $\mathbf{H}$ & & & & $\mathbf{H}$ \\
\hline $\begin{array}{l}\text { (c) Ability to design a system, component, or process to meet } \\
\text { desired needs within realistic constraints such as economic, en- } \\
\text { vironmental, social, political, ethical, health and safety, manu- } \\
\text { facturability, and sustainability }\end{array}$ & $\mathbf{H}$ & & & & $\mathbf{H}$ \\
\hline (d) Ability to function on multidisciplinary teams & & $\mathbf{H}$ & & & $\mathbf{H}$ \\
\hline $\begin{array}{l}\text { (e) Ability to identify, formulate, and solve engineering prob- } \\
\text { lems }\end{array}$ & $\mathbf{H}$ & & & & $\mathbf{H}$ \\
\hline (f) Understanding of professional and ethical responsibility & & $\mathbf{H}$ & & $\mathbf{H}$ & $\mathbf{H}$ \\
\hline (g) Ability to communicate effectively & & $\mathbf{H}$ & & $\mathbf{H}$ & $\mathbf{M}$ \\
\hline $\begin{array}{l}\text { (h) Broad education necessary to understand the impact of en- } \\
\text { gineering solutions in a global, economic, environmental, and } \\
\text { societal context }\end{array}$ & $\mathbf{M}$ & $\mathbf{M}$ & $\mathbf{M}$ & $\mathbf{H}$ & $\mathbf{M}$ \\
\hline $\begin{array}{l}\text { (i) Recognition of the need for, and an ability to engage in life- } \\
\text { long learning }\end{array}$ & $\mathbf{H}$ & & $\mathbf{H}$ & $\mathbf{H}$ & $\mathbf{H}$ \\
\hline (j) Knowledge of contemporary issues & M & M & $\mathbf{M}$ & $\mathbf{H}$ & M \\
\hline $\begin{array}{l}\text { (k) Ability to use the techniques, skills, and modern engineer- } \\
\text { ing tools necessary for engineering practice }\end{array}$ & $\mathbf{H}$ & & & & $\mathbf{M}$ \\
\hline
\end{tabular}

H: High; M: Medium; L: Low 
PAPER

Instruments \& Processes for the Assessment \& Evaluation of PEOs

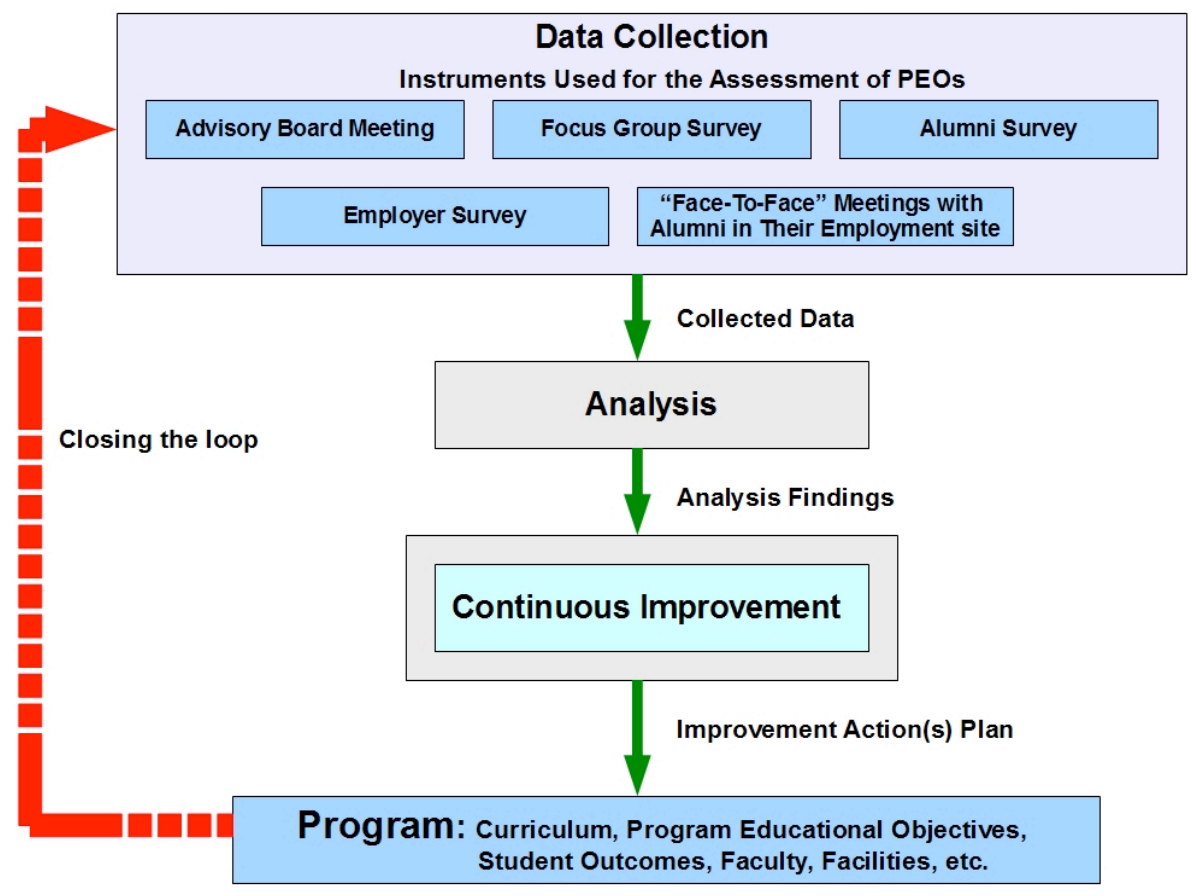

Figure 3. Instruments and processes used in the assessment of PEOs.

TABLE IV.

EXAMPLES OF LEVEL OF SATISFACTION OR TARGET DEFINED FOR EACH EDUCATIONAL OBJECTIVE

\begin{tabular}{|c|l|c|}
\hline $\begin{array}{c}\text { Program Educational } \\
\text { Objectives (PEOs) }\end{array}$ & \multicolumn{1}{|c|}{ Description } & $\begin{array}{c}\text { Satisfaction } \\
\text { Level / Tar- } \\
\text { get }\end{array}$ \\
\hline PEO 1 & $\begin{array}{l}\text { Possess essential professional software engineering skills that make them } \\
\text { confident to develop high-quality software solutions in various applica- } \\
\text { tion domains under various realistic constraints. }\end{array}$ & $\mathbf{7 0 \%}$ \\
\hline PEO 2 & $\begin{array}{l}\text { Engage and succeed in their professional careers through team work, } \\
\text { ethical behavior, proactive involvement, and effective communication. }\end{array}$ & $\mathbf{7 0 \%}$ \\
\hline PEO 3 & $\begin{array}{l}\text { Demonstrate an understanding of the importance of life-long learning } \\
\text { through professional development, practical training, and specialized } \\
\text { certifications. }\end{array}$ & $\mathbf{7 0 \%}$ \\
\hline PEO 4 & $\begin{array}{l}\text { Assume progressively managerial, leading, and influential roles in their } \\
\text { organizations and communities. }\end{array}$ & $\mathbf{3 0 \%}$ \\
\hline PEO 5 & $\begin{array}{l}\text { Pursue postgraduate studies and succeed in academic and research ca- } \\
\text { reers. }\end{array}$ & $\mathbf{1 0 \%}$ \\
\hline
\end{tabular}

Program educational objectives will not be all attained in the same way and with the same level. For example if we consider PEO \#1 in Table I, the target is $70 \%$ while for PEO \#4 the target is $30 \%$. Targets or levels of satisfaction for different PEOs are summarized in Table IV. The target or level of satisfaction defines the minimum level of satisfaction in order to consider a PEO attained. A target expresses the minimum percentage of respondents (for a specific instrument) who answered "agree" or "strongly agree" (in surveys where possible answers are "strongly agree", "agree", "neutral", "disagree", and "strongly disagree"). For example: for PEO \#1 in Table I, 70\% of respondents should answer "agree" or "strongly agree" in order to consider PEO \#1 met while, for PEO \#4, 30\% of respondents should answer "agree" or "strongly agree" in order to consider PEO \#4 met.

\section{1) Advisory Board Meetings}

The advisory board is one of the main stakeholders or constituents of a program. They play a key role in the assessment of the PEOs. A meeting should be held with the members of the advisory board on a regular basis (each 2 or 3 years ... or even each year) and get their views. Evidence related to Advisory board meeting could be the minutes of meetings held and improvement actions taken based on these meetings.

Defining clearly the objectives and roles of members of the advisory board is extremely important in order to increase its effectiveness [9]. To satisfy the ABET accreditation criteria with respect to program educational objectives, the advisory board members, as one of the key stakeholders, must be fully involved in defining and assessing the program educational objectives for a particular 
degree program. However the role of the advisory board is not necessarily limited to the definition and assessment of program educational objectives. It can also include influencing the curriculum itself, helping in recruiting graduates, participating in fundraising campaigns, etc.

\section{2) Focus Group Survey}

A focus group survey with the main constituents - External members of the Advisory Board, faculty members, and students - can be conducted to measure the views of each group about the relevance and attainment of PEOs. Evidence related to focus group survey could be the answers sheets of all constituents as well as the analysis and improvement actions taken based on the findings from this survey.

\section{3) Alumni Survey}

Alumni survey should be conducted with graduates from the program, few years after they graduate (3 to 5 years at least). The Alumni survey aims to measure clearly whether those graduates attained the PEOs defined for the program they graduated from or not. Evidence related to alumni survey could be the answers sheets of all alumni who participated as well as the analysis and improvement actions taken based on the findings from this survey.

Note that some alumni could be also members of the advisory board. The research survey described in [9] did not find any negative aspect resulting from the inclusion of alumni in the advisory board; it even indicates that alumni, when they are members of the advisory board of a program are the best advocates of the program.

\section{4) Employer Survey}

Employer survey should be conducted with employers of alumni from the program. The employer survey aims to measure clearly whether those graduates attained the PEOs defined for the program they graduated from or not. Evidence related to employer survey could be the answers sheets of all employers who participated as well as the analysis and improvement actions taken based on the findings from this survey.

5) "Face-to-Face" Meetings with Alumni in their employment site

A Face-to-Face meeting with alumni could be a stronger instrument than simply an alumni survey as it allows, to some extent, a direct contact and discussion with alumni. The face-to-face meeting with alumni aims to measure clearly whether those graduates attained the PEOs defined for the program they graduated from or not. Evidence related to face-to-face meetings could be the minutes of the meeting, a video-recording of the meeting, as well as the analysis and improvement actions taken based on the findings from this meeting.

There is an important note about Newly Established Programs. In fact, in the ABET procedures and policy manual (APPM) [3], it is clearly indicated that in order to apply for accreditation; a program must have graduates prior to the on-site visit. For a newly established program, and once the first batch of students graduate, normally need to wait at least 3 years in order to assess correctly the attainment of program educational objectives. Fortunately, ABET allows new programs to apply for accreditation immediately after having the first batch of graduates although PEOs cannot be really assessed. However, a preliminary assessment can be done. This preliminary assessment could for example measure the confidence or expectations of the different constituents in attaining PEOs few years later, based on what they have seen in the program so far: curriculum, faculty, facilities, etc. Such preliminary assessment can be conducted using a focus group survey only (among the instruments cited above) conducted with students, faculty members, and external members of the advisory board (alumni and employers are not yet there).

\section{B. Metrics}

Once data is collected through different instruments, it must be analyzed in order decide whether each PEO is attained or not. Two important questions arise here:

- How to combine the results given by different instruments?

- What metrics should be used in order to decide whether a PEO is met or not.

\section{1) Combination of different instruments}

Actually different instruments can be combined or not. When combining all instruments, there is a need to assign a weight to each instrument and calculate a final score for each educational objective as a weighted average of the scores given by each instrument. If we decide to not combine them, they can be seen as a multidimensional view on each PEO. The decision then would be to consider results of the majority of instruments. In the Software Engineering program we used the second option.

Note that the focus group survey, the alumni survey, and the employer survey give quantitative results while the advisory board meetings and the face-to-face meetings with alumni in their employment site give qualitative results. So only the instruments holding quantitative results can be combined. The instruments holding qualitative results must be analyzed separately.

Instruments holding quantitative results can be designed as questionnaires and surveys. A good guide as to how design effective surveys is described in [10]. In the Software Engineering program we designed surveys with a scale of 5 points: "Strongly Agree" corresponds to 5, "Agree" corresponds to 4, "Neutral" corresponds to 3, "Disagree" corresponds to 2, "Strongly Disagree" corresponds to 1 .

\section{2) Decision Metrics}

Different metrics can be calculated from the data collected. In the Software Engineering program we used two metrics:

- Average score: the average score on a scale of 5 as a combination of the percentage of respondents with respect to each scale point (Strongly Agree, Agree, Neutral, Disagree, and Strongly Disagree) as a weighted average.

- Percentage of respondents achieving the satisfactory level or above: the percentage of respondents achieving the satisfactory level or above. We consider here only respondents who answered "Strongly Agree" or "Agree"

\section{Sample of results and analysis}

As explained earlier, when analyzing data, collected through instruments mentioned, two (2) metrics will be calculated:

- The average score of all respondents. 
- The percentage of respondents above the satisfactory level (those who answered "strongly agree" and "agree").

The average score is used as indicative only while the $\%$ above the satisfactory level will be used to judge the attainment or not of an educational objective. The level of satisfaction or target depends on each education objective as mentioned above (see Table IV).

Table VII shows a sample of results from the focus group survey conducted with 3 groups of key constituents: students, faculty members, and external members of the advisory board. From the results in Table V, we can see that globally external members of the advisory board, faculty members, and students have high confidence in attaining the educational objectives of the program. PEO \#4 and PEO \#5 have lower score compared to PEO \#1, PEO $\# 2$, and PEO \#3 as the former ones have a target lower (see Table IV) than the latter ones (not all graduates will assume leadership positions or pursue graduate studies). Based on the level of satisfaction/target defined for each educational objective (see Table IV), we can say that all key program constituents have high confidence in attaining educational objectives. However (from Table VII):

- For PEO 1 the score is $65 \%$ for students when using the $\%$ of students who are above the satisfactory level metric. This means that some students are not confident enough to possess enough essential Software Engineering skills. A possible explanation of this is that, at the time of conducting this survey, students where in their $6^{\text {th }}$ semester. This means that, at that time, they did not take yet all courses and graduation projects in the curriculum. So the perception of some them was that they do not possess all essential Software Engineering skills. Communications actions should be undertaken with students to discuss and eventually adjust this perception.

- For PEO 3, the score is $66 \%$ for faculty when using the $\%$ of faculty who are above the satisfactory level metric. This indicates that some faculty members are not confident enough that all students, after graduation, will be life-long learners. So life-long learning skills should be reinforced in the program.

\section{Improvements Actions}

Examples of improvement actions are given below. These improvement actions are derived from the assessment of PEOs for a software engineering program using two instruments: focus group survey and meeting with the advisory board.

Improvement \#1: Vision changed

Source: First Advisory Board Meeting + Focus Group Survey with advisory board members

Description/Rationale: Make the program vision "international" instead of "national" or "regional". The program vision was as follows: "The Software Engineering Program aims to become the top education program in Software Engineering at the national and regional levels." and was changed to "The Software Engineering Program aims to become the top education program in Software Engineering at the national, regional, and international levels."

Improvement \#2: PEO \# 2 updated
Source: First Advisory Board Meeting + Focus Group Survey with advisory board members

Description/Rationale: Include in the objectives the concepts of pro-activity and anticipation. According to the advisory board members, graduates must have a proactive attitude in order to predict and solve problems. PEO \# 2 was as follows: "Engage and succeed in their professional careers through team work, ethical behavior, and effective communication." and was changed to be as follows: "Engage and succeed in their professional careers through team work, ethical behavior, proactive involvement, and effective communication."

Improvement \#3: Curriculum Update - include "different types of acquisition strategies and contracts in Software projects" as a topic in 2 courses

Source: First Advisory Board Meeting + Focus Group Survey with advisory board members

Description/Rationale: Include topics related to different types of acquisitions and contracts (outsourcing, internal development, customizing, etc.) in the "Software Project Management" course as well as in the "Software Engineering Ethics and Professional Practice" course.

Improvement \#4: Communication with student to explain PEOs and other related topics

Source: Focus group survey with students

Description/Rationale: Efforts have been doubled to explain to students the educational objectives we expect them to achieve after they graduate. An open communication meeting was organized with students to explain to them PEOs in particular and other topics such student outcomes as well as the importance and the role of students (through indirect assessment) to improve the program.

Improvement \#5: Include Students' representatives in the advisory board

Source: Focus group with faculty members

Description/Rationale: Representatives of students are added as members of the advisory board. They are responsible to bring the point of view of students with respect to various subjects related to the program.

Improvement \#6: Improve laboratories and practical work

Source: Focus group with Students

Description/Rationale: The program will have at least 3 dedicated laboratories in which various software systems and tools needed in the program must be installed and used in different Software Engineering courses. These tools include Rational RequisitePro, Rational Software Modeler, Rational Software Architect, Oracle DBMS, Oracle Designer, Oracle SQL developer, Eclipse/Java, etc.

In order to close the so called "assessment loop", and once these improvement actions are implemented, a new assessment cycle should start in order to see whether the identified issues have been solved or not. Depending on the outcome of this assessment, a new list of improvement actions might be defined. And the assessment process continues! 


\section{E. Systematicity and Sustainibility of the Assessment Process}

The assessment process is time and effort consuming activity that may be perceived by faculty members as a burden and overhead. This may make some faculty members resistant and refrain from fully engaging in this process. In order to make the process easier, it is definitely helpful to make it systematic and well organized so that, with time, faculty members and all stakeholders get used to it through a cumulative learning process.

Furthermore, if the assessment process is not well designed and faculty members are not fully engaged in it, it may become not sustainable in the sense that the assessment process will not continue in the future or it will continue but with a degraded quality.

Definitely making the process systematic and engaging faculty members and stakeholders in it will help to make the assessment process sustainable. We believe the approach proposed in this paper goes a step in this direction as it defines a list of guidelines to define and assess PEOs.

\section{CONCLUSION}

We discussed in this paper some guidelines related to the definition and assessment of program educational objectives for ABET accreditation by focusing on computing and engineering programs. PEOs have a link with student outcomes as well as with curriculum; thus the importance of defining and assessing them correctly. Examples of PEOs definition and assessment were given from a software engineering program. The definition of PEOs should cover both technical and professional aspects of the profession for which the program prepares students and should involve the main constituents or stakeholders of the program including faculty member, students, advisory board, alumni, and employers. PEOs must be in total symbiosis and alignment with the mission of the institution where the program is offered. The institutional mission could be at different levels including the university level, the college level, the department level, and the program level. The PEOs must also be mapped to student outcomes and, for each PEO, a list of student outcomes that helps in the preparation of students to achieving that PEO must be clearly identified. PEOs must be published and accessible to all stakeholders and interested public.

Assessment of PEOs is fundamental and includes data collection, data analysis, and improvement actions plan. Data collection could be done through different instruments including advisory board meeting, focus group survey, alumni survey, employer survey, etc. Data analysis could be done through the calculation of two metrics: average score and percentage of respondents achieving the satisfactory level. Based on the results of analysis, an improvement plan can be decided including a list of improvement actions to be implemented progressively in order to resolve the eventual issues identified during the analysis. Then, another assessment cycle should start after implementing the list of improvement actions to assess whether those improvement actions were effective and efficient in resolving the identified issues or not. Depending on the outcome of this assessment, a new list of improvement actions might be defined. And the assessment process continues.

Finally, let's note that ABET has changed its requirements regarding the assessment of PEOs. In fact, effective from the 2013-2014 accreditation cycle, it is no longer required to assess the attainment of PEOs. Still it is important to define them correctly, link them correctly with the institutional mission, and involve various constituents in their definition and revision. We believe that even if ABET has lessen the requirements in terms of PEOs assessment, programs can still assess their PEOs in order to know whether their graduates are attaining the PEOs defined for the program or not, and if not attained, eventually adjust the curriculum and other program components in order to solve the resulting issues.

\section{ACKNOWLEDGMENT}

We thank our colleagues, members of the ABETSoftware Engineering Department Committee and the ABET-College Committee at the College of Computer and Information Sciences (CCIS) at King Saud University for the fructuous discussions during our regular meetings. We thank also the Research Center, at the College of Computer and Information Sciences, for its support.

\section{REFERENCES}

[1] Accreditation Board of Engineering and Technology (ABET): http://www.abet.org

[2] ABET Computing Accreditation Criteria (CAC) and Engineering Accreditation Criteria (EAC), 2013-2014 Accreditation Cycle: http://www.abet.org/forms.shtml

[3] ABET Accreditation Policy and Procedures Manual (APPM), 2013-2014 Accreditation Cycle: http://www.abet.org/forms.shtml

[4] N. Abbadeni, A. Alghamdi, M. Batouche, A. Ghoneim. Combining Multiple Methods and Metrics for the Assessment of ABET Students Outcomes - The case of a Software Engineering Program. To appear in the International Conference on Engineering Education (ICEE), The international Network of Engineering Education and Research (iNEER), August 21-26, Belfast, UK, 2011.

[5] N. Abbadeni and A. Alghamdi: A Practical Review of ABET Accreditation Criteria - The Case of Software Engineering Programs. To appear in the International Conference on Engineering Education (ICEE), The international Network of Engineering Education and Research (iNEER), August 21-26, Belfast, UK, 2011.

[6] N.J. Mourtos, "Program Educational Objectives and Outcomes: How to Design a Sustainable, Systematic Process for Continuous Imporvement". Proceedinfs of the 36th ASEE/IEEE Frontiers in Education Conference, San Diego, CA, USA, October 28-31, 2006.

[7] N.J. Mourtos, "A Systematic Approach for Defining and Assessing Program Educational Objectives and Outcomes". Proceedings of the World Congress on Computer Science, Engineering, and Technology Education, March 7-10, 2006.

[8] M. Besterfield-Sacre, L. J. Shuman, H. Wolfe, C. J. Atman, J. McGourty, R. L. Miller, B. M. Olds, and G. Rogers, "Defining the Outcomes: A Framework for EC 2000", IEEE Transactions on Education, Vol. 43, No. 2, 2000, pp. 100-110. http://dx.doi.org/10.1109/13.848060

[9] S. R. Genheimer and R.L. Shehab, "A Survey of Industry Advisory Board Operation and Effectiveness in Engineering Education", Journal of Engineering Education (JEE), pp.169-180, April 2009.

[10] D.S. Walonick, "Survival Statistics", StatPac inc., 1997-2010. A short guide (24 pages) from this book is available at: http://www.statpac.com/surveys

[11] Y. Wang, "The Development of the IEEE/ACM Software Engineering Curricula", IEEE Canadian Review, 51(2), 16-20, 2005.

[12] T. Lethbridge et al, "SE2004: Recommendations for Undergraduate Software Engineering Curricula", IEEE Software, November/December 2006. http://dx.doi.org/10.1109/MS.2006.171

[13] ACM/IEEE-CS/AIS Joint Task Force "Computing Curricula The Overview Report", 2005.

[14] ACM/IEEE-CS Joint Task Force "Guidelines for Software Engineering Curricula", 2004.

[15] SWEBOK - Software Engineering Body of Knowledge, 2010. 


\section{AUTHORS}

Dr. Noureddine Abbadeni is an associate professor and vice-chair of the department of Software Engineering, College of Computer and Information Sciences, King Saud University. He is also an ABET Program Evaluator. (emails: nabbadeni@ksu.edu.sa; noureddine.abbadeni@usherbrooke.ca)

Dr. Ahmed Ghoneim is an assistant professor in the department of Software Engineering, College of Computer and Information Sciences, King Saud University. (email: ghoneim@ksu.edu.sa)

Dr. Abdullah Alghamdi is a professor and chair of the department of Software Engineering, College of Computer and Information Sciences, King Saud University. (email: ghamdi@ksu.edu.sa)

This article is an extended and modified version of a paper presented at the EDUCON2013 conference held at Technische Universität Berlin, Berlin, Germany from March 13-15, 2013.

\section{APPENDIX}

See next pages. 
PAPER

Program Educational ObJectives Definition And AsSessment for Quality AND ACCREDitation

TABLE V.

SAMPLE OF MAPPING BETWEEN STUDENT OUTCOMES AND COURSES IN A SOFTWARE ENGINEERING PROGRAM

\begin{tabular}{|c|c|c|c|c|c|c|c|c|c|c|c|}
\hline & 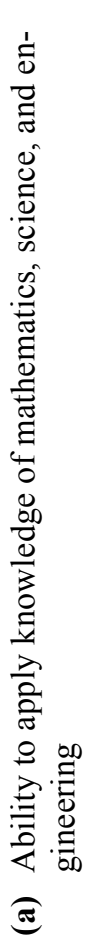 & 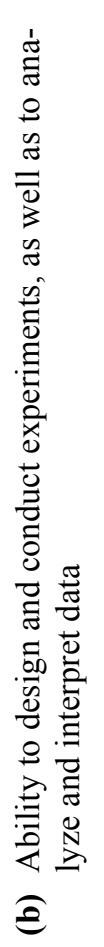 & 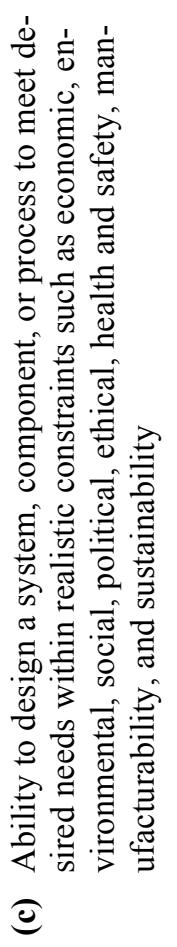 & 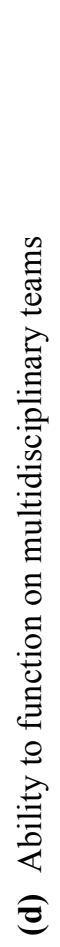 & 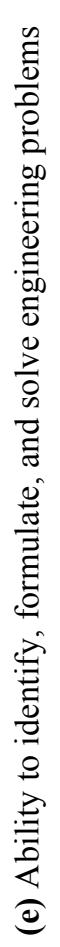 & 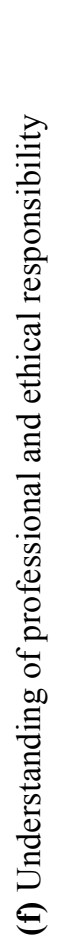 & 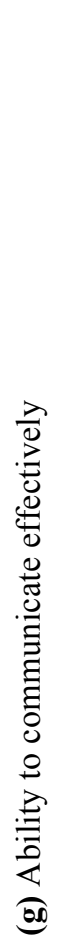 & 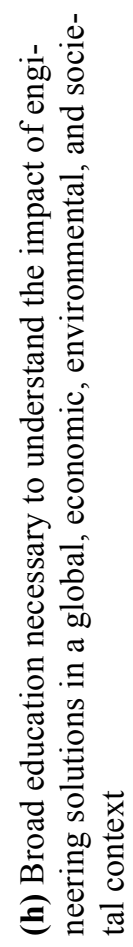 & 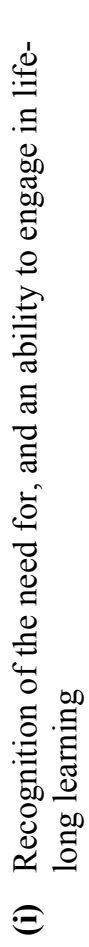 & 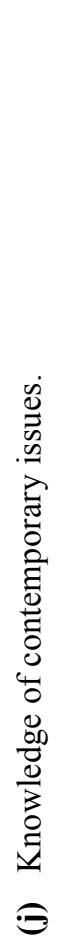 & 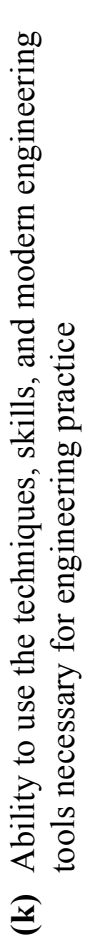 \\
\hline Requirements & & & & $\mathrm{L}$ & $\mathrm{M}$ & $\mathrm{L}$ & $\mathrm{L}$ & & & & $\bar{M}$ \\
\hline Process \& Model- & & & $\bar{M}$ & & $\mathrm{H}$ & & & & & & $\mathrm{H}$ \\
\hline Architecture \& De- & & $\mathrm{H}$ & $\mathrm{H}$ & & $\mathrm{M}$ & & $\mathrm{M}$ & & & & $\mathrm{H}$ \\
\hline Quality Assurance & $\mathrm{L}$ & & $\mathrm{H}$ & & & & & & & & $\mathrm{M}$ \\
\hline Testing & M & $\mathrm{H}$ & & & & & & & & & M \\
\hline Construction & & & $\mathrm{H}$ & $\mathrm{M}$ & $\mathrm{H}$ & & $\mathrm{H}$ & & & & $\mathrm{H}$ \\
\hline Maintenance & $\mathrm{H}$ & $\mathrm{H}$ & & & & & & & & & $\mathrm{H}$ \\
\hline Project Manage- & & & & $\mathrm{L}$ & $\mathrm{H}$ & & $\mathrm{M}$ & & & & $\mathrm{H}$ \\
\hline Ethics \& Practice & & & & $\mathrm{M}$ & & $\mathrm{H}$ & $\mathrm{H}$ & $\mathrm{H}$ & $\mathrm{H}$ & $\mathrm{H}$ & \\
\hline Capstone Project & $\mathrm{H}$ & $\mathrm{H}$ & $\mathrm{H}$ & $\mathrm{H}$ & $\mathrm{H}$ & $\mathrm{H}$ & $\mathrm{H}$ & $\mathrm{H}$ & $\mathrm{H}$ & $\mathrm{H}$ & $\mathrm{H}$ \\
\hline
\end{tabular}


TABLE VI.

SUMMARY OF INSTRUMENTS USED TO ASSESS THE ATTAINMENT OF PROGRAM EDUCATIONAL OBJECTIVES IN THE SOFTWARE ENGINEERING PROGRAM

\begin{tabular}{|c|c|c|c|c|c|c|}
\hline 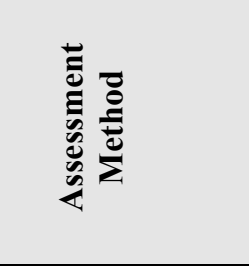 & 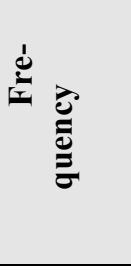 & 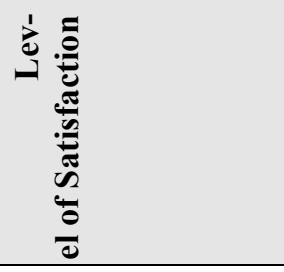 & 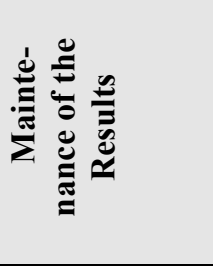 & 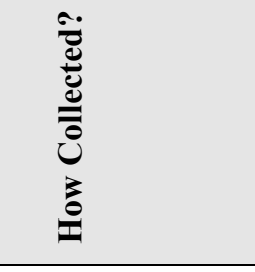 & 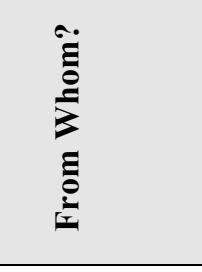 & 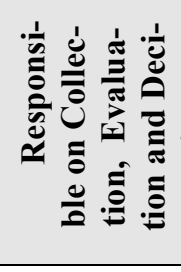 \\
\hline Alumni Survey & $\begin{array}{l}\text { Each } 3 \\
\text { Years }\end{array}$ & $\begin{array}{l}\text { Depends on each } \\
\text { Educational Objec- } \\
\text { tive (see Table 4) }\end{array}$ & $\begin{array}{l}\text { PEOs Assess- } \\
\text { ment Portfolio }\end{array}$ & $\begin{array}{c}\text { Paper/ } \\
\text { Electronic }\end{array}$ & Alumni & $\begin{array}{c}\text { Assessment } \\
\text { Committee } \\
\text { Department } \\
\text { Council }\end{array}$ \\
\hline $\begin{array}{l}\text { Employer } \\
\text { Survey }\end{array}$ & $\begin{array}{l}\text { Each } 3 \\
\text { Years }\end{array}$ & $\begin{array}{l}\text { Depends on each } \\
\text { Educational Objec- } \\
\text { tive (see Table 4) }\end{array}$ & $\begin{array}{l}\text { PEOs Assess- } \\
\text { ment Portfolio }\end{array}$ & $\begin{array}{c}\text { Paper/ } \\
\text { Electronic }\end{array}$ & $\begin{array}{c}\text { Employers of } \\
\text { program's } \\
\text { graduates }\end{array}$ & $\begin{array}{c}\text { Assessment } \\
\text { Committee } \\
\text { Department } \\
\text { Council }\end{array}$ \\
\hline $\begin{array}{c}\text { Advisory } \\
\text { Board Meeting }\end{array}$ & $\begin{array}{l}\text { Each } 3 \\
\text { Years }\end{array}$ & $\begin{array}{l}\text { Depends on each } \\
\text { Educational Objec- } \\
\text { tive (see Table 4) }\end{array}$ & $\begin{array}{l}\text { PEOs Assess- } \\
\text { ment Portfolio }\end{array}$ & $\begin{array}{l}\text { Paper/Meeting } \\
\text { Minutes }\end{array}$ & $\begin{array}{c}\text { External } \\
\text { Members of } \\
\text { the Advisory } \\
\text { board }\end{array}$ & $\begin{array}{c}\text { Assessment } \\
\text { Committee } \\
\text { Department } \\
\text { Council }\end{array}$ \\
\hline $\begin{array}{l}\text { Focus Group } \\
\text { Survey } \\
\text { (All constitu- } \\
\text { ents) }\end{array}$ & $\begin{array}{l}\text { Each } 3 \\
\text { Years }\end{array}$ & $\begin{array}{l}\text { Depends on each } \\
\text { Educational Objec- } \\
\text { tive (see Table 4) }\end{array}$ & $\begin{array}{l}\text { PEOs Assess- } \\
\text { ment Portfolio }\end{array}$ & $\begin{array}{c}\text { Paper/ } \\
\text { Electronic }\end{array}$ & $\begin{array}{c}\text { Students } \\
\text { Faculty } \\
\text { members } \\
\text { External } \\
\text { Members of } \\
\text { the Advisory } \\
\text { board } \\
\text { Employers } \\
\text { Alumni }\end{array}$ & $\begin{array}{c}\text { Assessment } \\
\text { Committee } \\
\text { Department } \\
\text { Council }\end{array}$ \\
\hline $\begin{array}{l}\text { "Face-to- } \\
\text { Face" Meet- } \\
\text { ings with } \\
\text { Alumni } \\
\text { In their em- } \\
\text { ployment site }\end{array}$ & $\begin{array}{l}\text { Each } 3 \\
\text { Years }\end{array}$ & $\begin{array}{l}\text { Depends on each } \\
\text { Educational Objec- } \\
\text { tive (see Table 4) }\end{array}$ & $\begin{array}{l}\text { PEOs Assess- } \\
\text { ment Portfolio }\end{array}$ & $\begin{array}{c}\text { Verbal/Interview } \\
\text { Video } \\
\text { Recordings }\end{array}$ & Alumni & $\begin{array}{c}\text { Assessment } \\
\text { Committee } \\
\text { Department } \\
\text { Council }\end{array}$ \\
\hline
\end{tabular}


TABLE VII.

EXAMPLE OF ASSESSMENT RESULTS FROM ONE ASSESSMENT INSTRUMENT USED IN THE SOFTWARE ENGINEERING PROGRAM: ASSESSMENT OF PEOS ATTAINMENT BY DIFFERENT CONSTITUENTS USING A FOCUS GROUP SURVEY (ALL NUMBERS REPRESENT PERCENTAGES)

\begin{tabular}{|c|c|c|c|c|c|c|c|}
\hline & \multirow{3}{*}{ 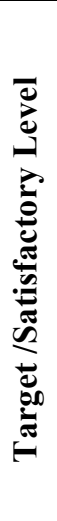 } & \multicolumn{6}{|c|}{ Assessment Results - Focus Group Survey } \\
\hline & & \multicolumn{2}{|c|}{ Students } & \multicolumn{2}{|c|}{$\begin{array}{l}\text { Faculty } \\
\text { Members }\end{array}$} & \multicolumn{2}{|c|}{$\begin{array}{l}\text { External } \\
\text { Members of } \\
\text { the Adviso- } \\
\text { ry Board } \\
\end{array}$} \\
\hline & & 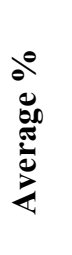 & 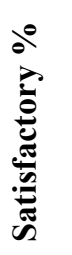 & 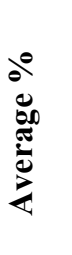 & 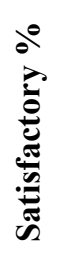 & 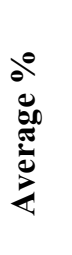 & 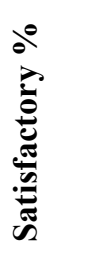 \\
\hline $\begin{array}{l}\text { PEO } 1 \text { - Possess essential professional software engineering } \\
\text { skills that make them confident to develop high-quality soft- } \\
\text { ware solutions in various application domains under various } \\
\text { realistic constraints. }\end{array}$ & 70 & 73 & 65 & 86 & 100 & 92 & 100 \\
\hline $\begin{array}{l}\text { PEO } 2 \text { - Engage and succeed in their professional careers } \\
\text { through team work, ethical behavior, proactive involvement, } \\
\text { and effective communication. }\end{array}$ & 70 & 90 & 93 & 84 & 100 & 80 & 80 \\
\hline $\begin{array}{l}\text { PEO } 3 \text { - Demonstrate an understanding of the importance of } \\
\text { life-long learning through professional development, practical } \\
\text { training, and specialized certifications. }\end{array}$ & 70 & 78 & 72 & 75 & 66 & 80 & 80 \\
\hline $\begin{array}{l}\text { PEO } 4 \text { - Assume progressively managerial, leading, and influ- } \\
\text { ential roles in their organizations and communities. }\end{array}$ & 30 & 76 & 75 & 79 & 77 & 76 & 60 \\
\hline $\begin{array}{l}\text { PEO } 5 \text { - Pursue postgraduate studies and succeed in academic } \\
\text { and research careers. }\end{array}$ & 10 & 68 & 41 & 88 & 100 & 72 & 60 \\
\hline
\end{tabular}

